\title{
Interweaving Industrial Ecology and Ecological Modernization: A Comparative Bibliometric Analysis
}

\author{
Feng Han ${ }^{1, * \mathbb{C}}$, Zhangcong Feng ${ }^{1}$, Chao Wang ${ }^{2}$, Nujie Yang ${ }^{1}$, Dong Yang ${ }^{1}$ and Feng Shi ${ }^{1}$ \\ 1 Institute of Science and Technology for Development of Shandong, \\ Qilu University of Technology (Shandong Academy of Sciences), Jinan 250100, China; \\ fengzhc@sdas.org (Z.F.); 10431200846@stu.qlu.edu.cn (N.Y.); yangdong@qlu.edu.cn (D.Y.); \\ shifeng@sdas.org (F.S.) \\ 2 Information Research Institute of Shandong Academy of Sciences, Qilu University of Technology \\ (Shandong Academy of Sciences), Jinan 250100, China; wangchao1@sdas.org \\ * Correspondence: hanf@sdas.org
}

Citation: Han, F.; Feng, Z.; Wang, C.; Yang, N.; Yang, D.; Shi, F.

Interweaving Industrial Ecology and Ecological Modernization: A Comparative Bibliometric Analysis. Sustainability 2021, 13, 9673.

https://doi.org/10.3390/su13179673

Academic Editor: Zenon Foltynowicz

Received: 29 June 2021

Accepted: 21 August 2021

Published: 27 August 2021

Publisher's Note: MDPI stays neutral with regard to jurisdictional claims in published maps and institutional affiliations.

Copyright: (c) 2021 by the authors. Licensee MDPI, Basel, Switzerland. This article is an open access article distributed under the terms and conditions of the Creative Commons Attribution (CC BY) license (https:// creativecommons.org/licenses/by/ $4.0 /)$
Abstract: Although industrial activity has brought about rapid economic growth, it also faces the dual challenges of resource constraints and environmental pressure. Industrial ecology (IE) and ecological modernization (EM) are two theories regarding the conceptualization and implementation of sustainable development that emerged from the natural and social sciences, respectively. Over the past three decades, scholars have conducted copious amounts of theoretical and applied research on IE and EM, but comparative studies from an interdisciplinary perspective on the relationship between the two remain relatively rare. On the basis of a bibliometric analysis, this study offers a comprehensive examination of the background, theoretical connotations, and main content of IE and EM, also exploring the role of both theoretical perspectives in the promotion of sustainable industrial development. The findings are fourfold: (1) the research on IE and EM has been increasing year by year, particularly in the past decade; (2) the research is mostly concentrated in developed countries such as the United States and European Union member nations, and contributions from China have increased significantly in recent years; (3) IE has a broader research community than EM and has evolved clearer and more specific research contents and methods; and (4) IE, which analyzes the problems of specific industrial systems, and EM, which constitutes a higher-level institutional policy design, exhibit a trend of cross-fertilization. This study provides a reference for building a more systematic and comprehensive theoretical system of ecological transformation and discusses the future research directions in this field.

Keywords: industrial ecology; ecological modernization; green transformation; comparative analysis; bibliometric analysis

\section{Introduction}

Economic development and technological progress have raised the standard of living and improved the overall quality of global human life, but at the same time, the shortage of resources and environmental pollution resulting from the industrialization process has increasingly become a bottleneck that limits the development of human society [1-3]. In the early stage of industrialization, because of shallow environmental awareness and lack of planning, industrial development was characterized by a fragmented structure and a low environmental threshold, which led to the traditional industrial development approach of "pollute first, control later" [4]. The intensification of environmental hazards and the emergence of the global energy crisis have raised awareness in human society regarding the environmental crisis, spurring the exploration of a green, circular, and sustainable development model to improve the ecological environment [5]. In 1987, sustainable development was introduced in "Our Common Future," which encouraged the global population to consider achieving the harmonious mutual development of society, economy, 
and environment [6]. Following multiple theories of ecological transformation put forth in recent years, such as industrial ecology (IE) and ecological modernization (EM), sustainable development calls for a green transformation of traditional development models $[4,7]$.

IE and EM are two approaches that conceptualize the implementation of sustainable development that have emerged in the United States and northwestern Europe [8]. IE originated from a core subject matter of industrial metabolism, industrial symbiosis, and the metaphor of the industrial ecosystem as similar to a natural ecosystem. It represents an integrated interdisciplinary field that covers ecology, economics, environmental science, and system dynamics (SD) $[1,9,10]$. IE applies a bottom-up research approach, starting from specific industrial systems that produce pollution, and seeks to prevent and treat pollution in the whole process through clean production, circular economy, and industrial symbiosis to achieve green development. By contrast, EM emerged from the European environmental movement and environmental policy practice and presents a reexamination and rethinking of the current incompatibility of economic growth and environmental protection. Adopting a top-down approach, EM seeks environmental reform and ecological transformation from macro-level (national, international, and regional) perspectives and approaches, such as policy and institutional innovation and market mechanisms, to resolve environmental conflicts and the resulting social challenges. As such, sociologists are more active in the EM field. Both theories have been in existence for more than 30 years now, and countries worldwide have accepted resulting guidance on industrialization activities to varying degrees, some of which have achieved positive benefits [11,12]. For instance, eco-industrial development and IS practices have led to economic growth and low-carbon development with improved eco-efficiency [13].

However, with the increasing complexity of industrial activities and heightened stringency of environmental standards, it has progressively become more challenging for a single theory to provide effective guidance to advance eco-efficiency improvement. In 1995, the Porter hypothesis suggested that environmental regulation could stimulate eco-innovation and further influence environmental performance and competitive performance [14]. However, the high initial investment costs of green technologies and green production practices and the uncertainty of whether they contribute to increased economic competitiveness have resulted in resistance in some operators' willingness to make a green transition [7]. Meanwhile, concrete policy instruments are needed to support the implementation of industrial green transformation measures (e.g., economic incentives, regulation, and voluntary instruments) [15], besides comprehensive institutional arrangements. Both theories represent vital approaches for solving resource and environmental challenges. Integrating IE and EM research may expand into more instructive perspectives to lead the ecological transition and sustainable development research and practice. Unfortunately, current academic research on IE and EM is still relatively disconnected, and only a very few articles (e.g., Deutz 2009 [8]) have conducted research from the perspective of comparing IE and EM. IE scholars are less likely to address institutions, policies, and other elements of EM concern, whereas EM research lacks concrete means of implementation. This state of affairs has hindered the advancement of the industrial sustainability process from developing a more practical and systematic perspective. To fill the gap, this study endeavors to complement the theoretical system of sustainable development by reviewing and comparing the development of IE and EM theories.

On the basis of the bibliometric method, this study conducts a comparative analysis from the proposed background, theoretical connotation, research scale, and research content to reveal the application and guiding significance of the two theories in the green transformation of industries and to provide references for management decisions and sustainable industrial development. The remainder of this paper is organized into four sections. Section 2 introduces the data sources and processing tools, and methods used in the bibliometric investigation. Section 3 presents the results, including the general trends of IE and EM literature published over the years, the contributions of different countries and regions, the author collaboration network, and an analysis of the evolution 
of relevant keywords. Section 4 provides a comparative examination of the background origin, connotation characteristics, main contents, and principles of IE and EM. Finally, the last two sections present discussions and conclusions.

\section{Materials and Methods}

\subsection{Data Collection and Cleanup}

The Web of Science (WoS) is one of the most widely used databases for bibliometric analyses in the sciences [16]. It provides standardized records for citation analysis and allows complete citation records to be downloaded into text or tab format, which is compatible with most literature analysis tools, such as CiteSpace and VOSviewer [17]. Data collection in this research was based on the WoS Core Collection (including SCIEXPANDED, SSCI, A and HCI, CPCI-S, CPCI-SSH, CCR-EXPANDED, and IC), with a time span of 1900-2020. Additionally, only the article type of publications was considered because of their original contributions.

As the topic of industrial symbiosis is a significant subfield in the academic domain of IE, this study applied the research string of "TOPIC $=$ ("industrial ecology" OR "industrial symbiosis")" to retrieve IE publications. Conversely, for EM, the search equation was "TOPIC = ("ecological modernization" OR "ecological modernisation")." A TOPIC search retrieves the words from the title, abstract, author keywords, and keywords plus. Two file formats were exported from the WoS: Plain Text for CiteSpace and Tab-delimited for VOSviewer. A total of 4286 records of IE and 1024 records of EM were found, separately. Each record included the title, author names, publication years, keywords, abstracts, journals, references, and other information for analysis.

To obtain more accurate information, data cleaning was performed. Several synonyms were identified, such as "industrial ecosystem" and "industrial ecosystems," "carbon dioxide emissions" and " $\mathrm{CO}_{2}$ emissions," "ecological modernization" and "ecological modernisation" in the keywords and "Geng Y" and "Geng Yong," "Tsuyoshi Fujita" and "Fujita Tsuyoshi," "Mol, Arthur P. J." in the author names. Two tools were used to clean up the data for this investigation. One was the thesaurus file of VOSviewer, which presents a text file with 2 columns, a label column, and a replace by column that enabled us to perform data cleaning. The other was the alias file of CiteSpace. An alias file was created in the project folder to merge different types of aliases.

\subsection{Analytical Methods}

Bibliometric analysis is a widely used analytical tool that enables quantitative analysis of the literature published in a given field [18]. By using a wide range of metrics and methods (e.g., citation analysis [19]), it can reveal the current distribution of the research field and predict research trends $[20,21]$. Besides, the visual analysis enables the graphical presentation of large amounts of literature information, which facilitates bibliometric summaries of the number of publications, research hotspots, research methods, author distribution, etc.

Bibliometric and visual analysis methods were applied to study the development history of IE and EM from the perspective of keyword co-occurrence, author collaboration networks, and country/region contributions. CiteSpace is a scientific literature analysis tool that aids the discovery of research hotspots and evolutionary paths in scientific fields through the measurement of domain-specific literature [22]. CiteSpace was used to organize basic information, such as the number of articles published per year for IE and EM, the frequency of keywords, the number of articles published per author, and other considerations for further examination using Gephi, R, and tabular forms. Additionally, VOSviewer offers a scientific knowledge mapping analysis tool that is mainly suited to the analysis of literature data and is distinguished by its graphic presentation capabilities [23]. We used VOSviewer for the presentation of author collaboration network graphs, wherein each node represents an author, the size of the node represents the number of author papers, different colors represent different collaboration groups, and the lines between 
points represent collaborative relationships. Moreover, for better graphical presentation, $\mathrm{R}$ language and Gephi were also used for visual graphical presentation. $\mathrm{R}$ is a free, opensource software with excellent statistical and data processing capabilities [24]. We imported country contribution data of IE and EM at different periods into RStudio and used ggplot2 packages to form bubble charts to facilitate our analysis. Gephi is an open-source software for graph and network analysis [25], which compiles and imports notes and edges files to form a network map of the keywords that arise in different periods. The thicker the line between nodes, the more times the keyword appears in that period. Furthermore, on the basis of the bibliometric results and visualization mapping, the study compares and analyzes the similarities and differences between IE and EM further in terms of background origin, connotation, and research content.

\section{Bibliometric Results}

\subsection{General Trends and Geographical Distribution}

Figure 1a presents the annual number of publications from 1960 to 2020. Considering the small amount of literature before 1990 (occasional articles) and the fact that no original article was found, this paper mainly uses data from 1991 to 2020 for the bibliometric analysis. More articles have been published on IE, with 4286 literature records, whereas EM has 1024 records. The number of articles published annually in IE exhibits an upward trend, with an average annual exponential growth of 18\%, from 4 articles in 1991 to 505 articles in 2020. The number of articles per year has shown a significant increase in the years following 2010; more than half of the 4286 articles were published in the last 5 years. The number of publications per year in EM is gradually increasing, from one article in 1991 to 82 articles in 2020.

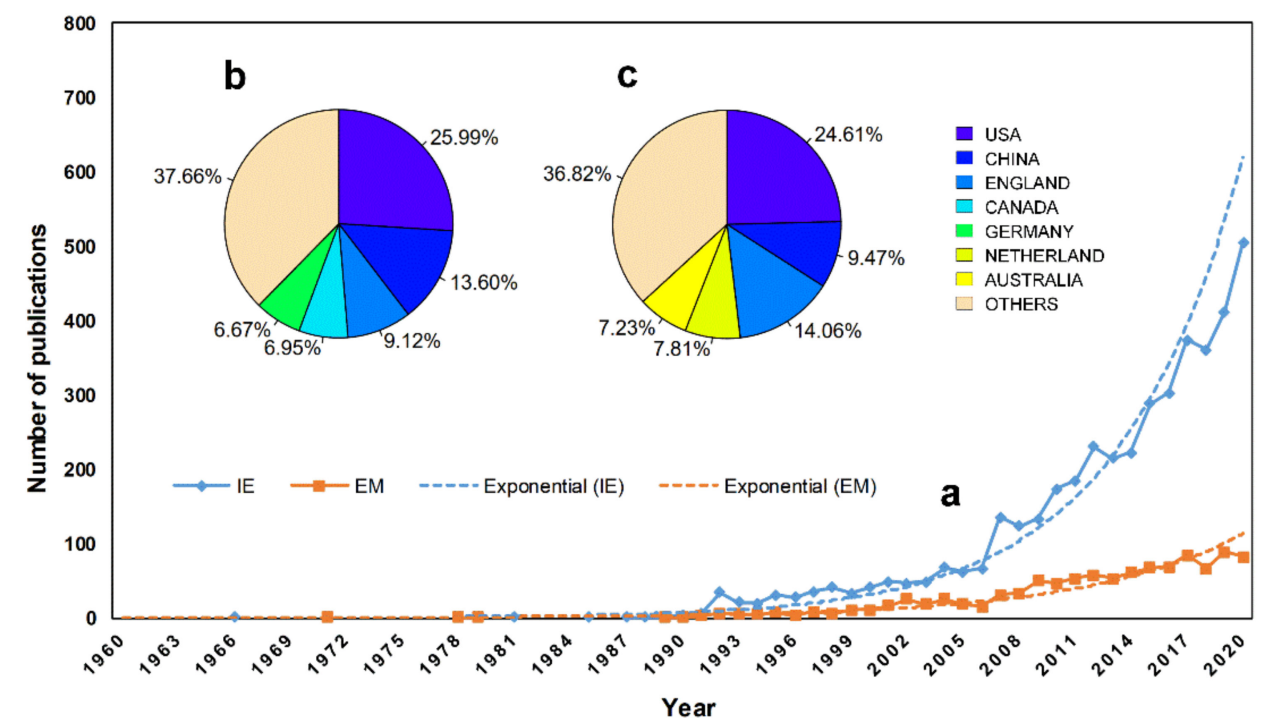

Figure 1. General publication of Industrial Ecology and Ecological Modernization. (a) Annual number of publications of IE and EM in 1960-2020; (b) proportion of publications in the top 5 most productive countries/territories of IE; (c) proportion of publications in the top 5 most productive countries/territories of EM.

The statistical analysis of countries/territories revealed that the top 5 most productive countries, as displayed in Figure 1b,c, accounted for $62.34 \%$ and $63.19 \%$ of the total publications of IE and EM, respectively. Most documents were published in the United States in both fields during 1991-2020, followed by the People's Republic of China (hereinafter referred to as China) and the United Kingdom. In the field of IE, the countries with the fourth and fifth-highest numbers of publications were Germany and Canada, respectively, whereas, in the field of EM, The Netherlands and Australia represented the fourth and fifth-highest, respectively. 
Figure 2 further presents the evolution of the number of articles published in each country during 1991-2020. The size of each bubble represents the contribution of each country in each period of IE and EM research. In the field of IE, research began in the United States in the early 1990s, whereas articles from other countries began appearing in the WoS database in the late 1990s, with scholars from China surpassing other countries to become the second-largest contributors in 2010, and catching up with the United States in terms of the number of articles published after 2017. In the field of EM, relevant literature began to be published in Germany, The Netherlands, and the United States in the early 1990s, and scholars in other countries started to contribute relevant articles around 2000. Articles in China and the United Kingdom started to match the United States in terms of the number of articles in 2016. The number of publications per year in each country was less than that of IE.

a

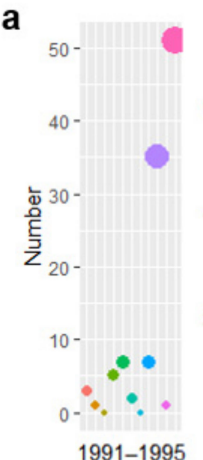

b

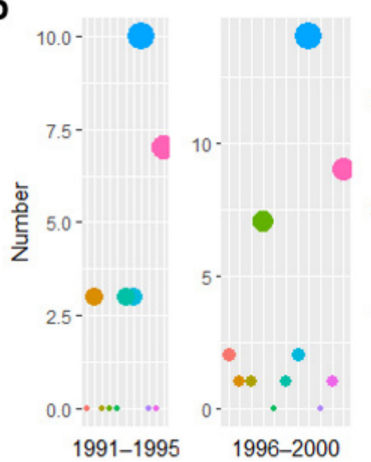

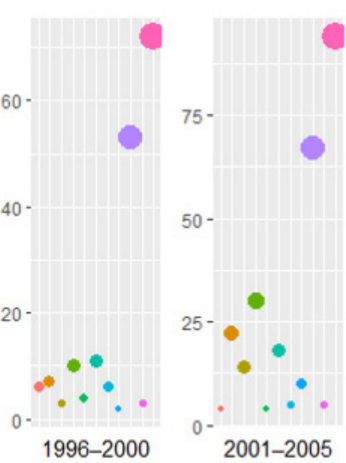
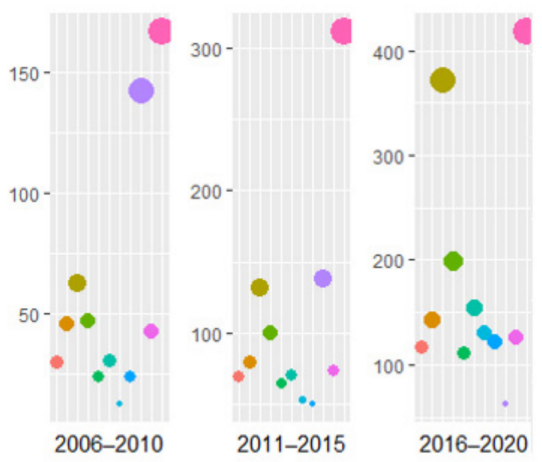

Country_IE

- australia

- canada

- CHINA

- england

- france

- germany

- italy

- netherlands

- OTHERS

- SPAIN

- usa
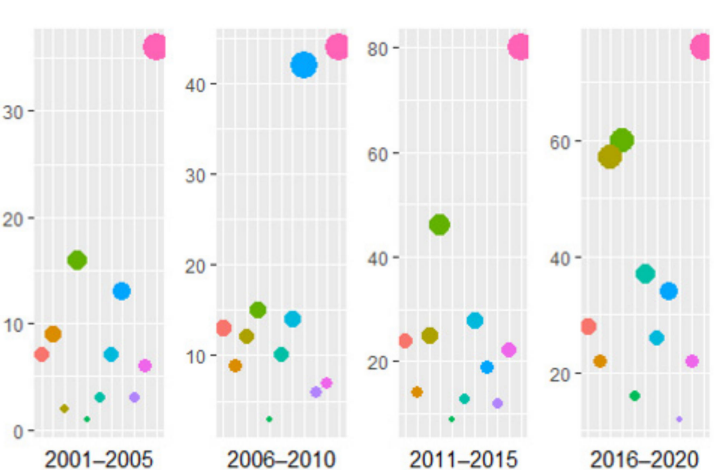

Country_EM

- australia

- canada

- CHINA

- england

- france

- germany

- Netherlands

- others

- POLAND

- SWEDEN

- UsA

Figure 2. Development trends of the top 10 productive countries/territories in 1991-2020. (a) Top 10 productive countries/territories for IE; (b) Top 10 productive countries/territories for EM.

In both of these areas, the United States was the most productive country during 1991-2020, and China became the second most productive country. Moreover, researchers in developed countries have made more contributions and published more articles due to the early industrialization of developed countries, which experienced environmental problems earlier and awakened environmental awareness the soonest.

\subsection{Collaborations among Authors}

In this section, a cooccurrence analysis of the collaborative network among authors was performed (As illustrated in Figure 3, isolated nodes are ignored). 

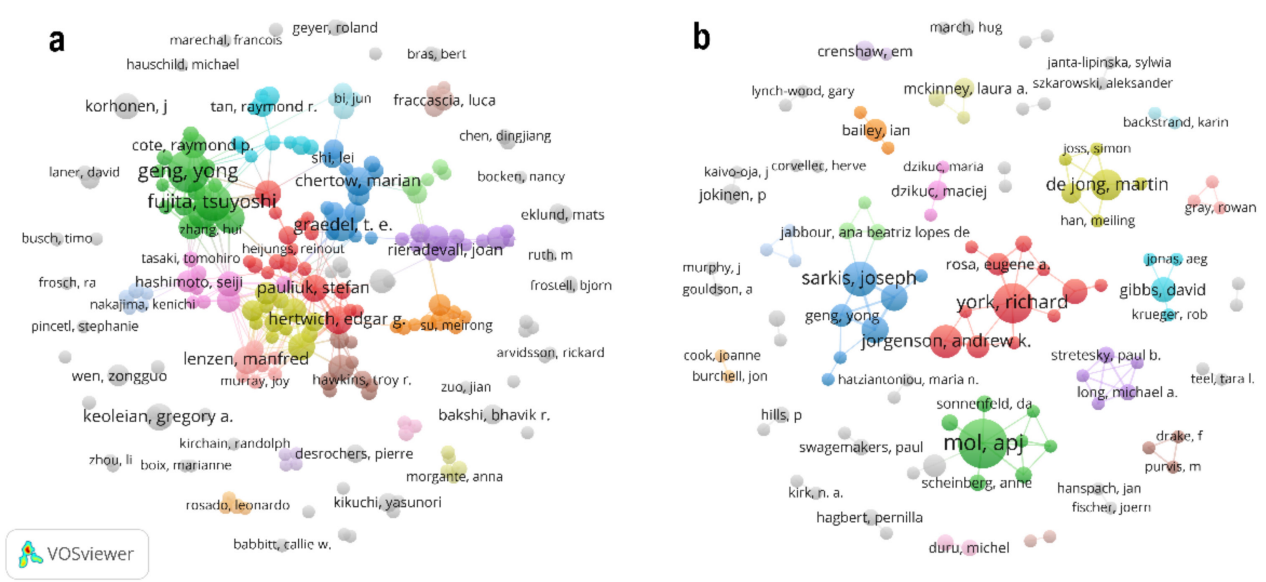

Figure 3. Coauthorship network during 1991-2020. (a) Coauthorship network of IE with the threshold of a minimum of five publications; (b) coauthorship network of EM with the threshold of a minimum of two publications.

In the field of IE, collaborations between authors who published more than five articles are shown in Figure 3a. The largest component contains 16 authors, most of whom are American, Chinese, and Japanese researchers. Yong Geng, from Shanghai Jiao Tong University, China, is the most prolific researcher, with 44 articles (1.03\%). Tsuyoshi Fujita (32 articles, $0.75 \%$ ) from the University of Tokyo, Japan, has a close collaborative research relationship with Yong Geng and Liang Dong ( 24 articles, $0.56 \%$ ) on the subjects of industrial symbiosis and urban symbiosis in China as well as Japan [26-28]. Richard Wood (19 articles, $0.44 \%$ ) and his colleagues at the Norwegian University of Science and Technology mainly used multiregional input-output analysis (IOA) to explore environmental impact issues [29-31]. Finally, Stefan Pauliuk (19 articles, 0.44\%), also from the Norwegian University of Science and Technology, has produced a lot of work on the analytical assessment of socioeconomic metabolism [32,33].

In the field of EM, collaborations between authors who published more than two articles are shown in Figure $3 b$. The largest collaborative network was formed by 11 authors, with Richard York (14 articles, 1.37\%) from the University of Oregon in the United States and his colleagues mainly focused on the analysis of drivers of environmental impact [34,35]. APJ Mol, from Wageningen University and Research in The Netherlands, was the most prolific author, with 22 articles $(2.15 \%)$. Mol's work focuses on the environmental crisis and institutional reform in modern societies from the perspective of environmental sociology and investigates the EM process in non-European countries [36-38]. Joseph Sarkis (12 articles, $1.17 \%$ ) from Worcester Polytechnic Institute in the United States had a close collaboration with Qinghua Zhu (seven articles, $0.68 \%$ ) from Shanghai Jiao Tong University in China on green supply chain management [39,40]. Martin De Jong ( 9 articles, $0.88 \%$ ) from Erasmus University Rotterdam in The Netherlands produced several efforts on city brand identity and practices adopted in different industry and regional development paths $[41,42]$.

The results demonstrate that, compared with EM, there are more scholars and groups engaged in IE research, and its coauthorship network is more complex. Scholars who study IE have published more. In their respective fields, transnational and institutional academic cooperation between authors is a common phenomenon.

\subsection{Keyword Analysis}

Figure 4 illustrates the evolution of high-frequency keywords in different periods of IE and EM. The green, blue, and orange nodes represent the time periods, IE, and EM, respectively. The thickness of the line represents the number of keyword occurrences in that period. Considering that the two fields had just begun to develop and had a small 
number of articles in 1991-2000, the decade was integrated into one time period, and all subsequent periods were displayed in 5-year increments.

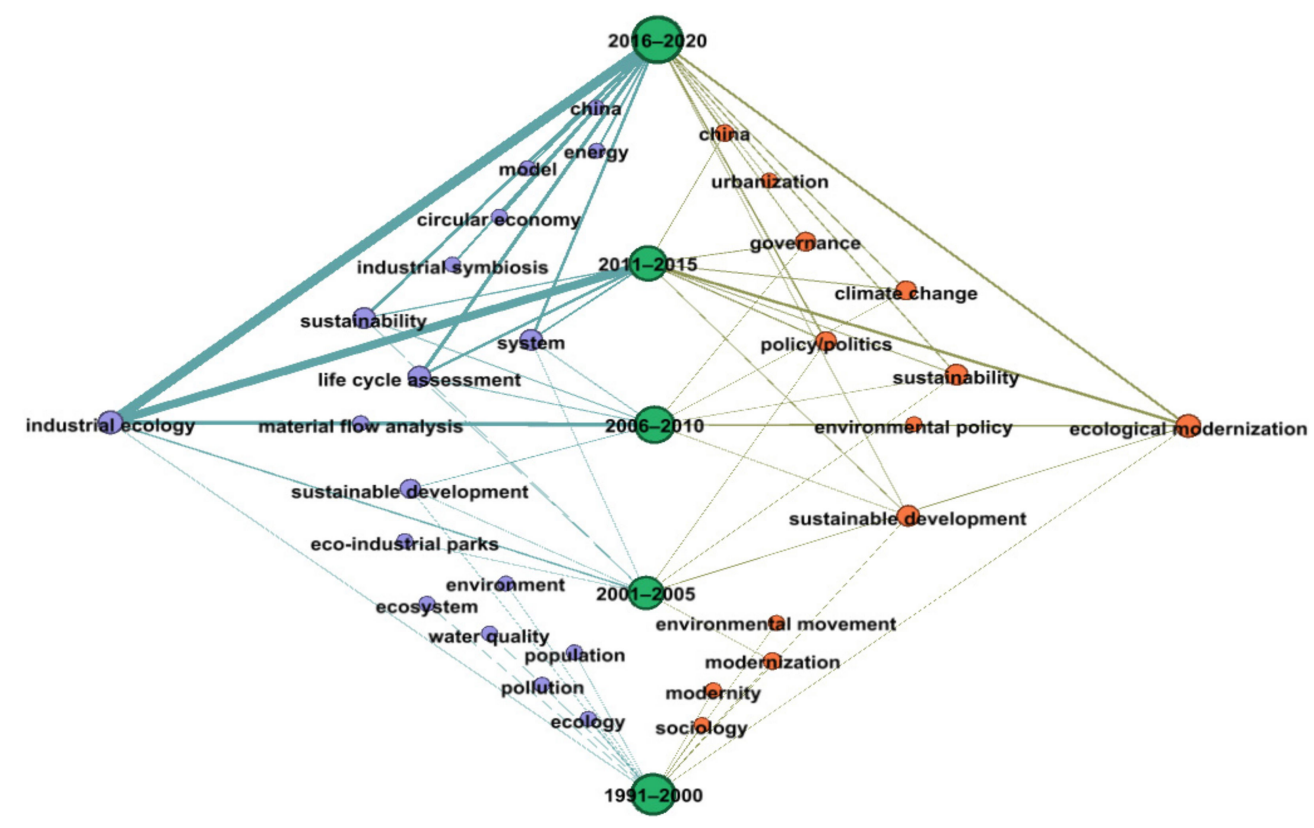

Figure 4. High-frequency keywords in IE and EM.

"Ecology" and "ecosystem" were high-frequency words in the early stage of IE, as IE originated, in part, from the observation of industrial symbiosis and the analogy between industrial ecosystems and biological ecosystems [1]. Moreover, "population," "pollution," "environment," and "water quality" illustrated the early studies' focus on the relationship between humans and nature. "Sustainable development" is repeatedly mentioned in articles, echoing "Our Common Future" from 1987 and the "Rio Declaration on Environment and Development" and "Agenda 21" adopted by the Environment and Development Conference in 1992, which led to subsequent research on "sustainability," "cleaner production," and the "circular economy." Since 2000, the frequency and ranking of "life cycle assessment (LCA)" have increased significantly, representing the most commonly used analysis method in the field of IE, along with "material flow analysis (MFA)" and "input-output analysis (IOA)." The high frequency of the word "system" reflects the more systemic perspective and approach of IE's treatment of resource and environmental issues. "Eco-industrial parks (EIPs)" was a high-frequency keyword during 2001-2005, and scholars have conducted a series of case studies on the construction of EIPs in the United States, Europe, China, Australia, Singapore, Japan, and other countries/regions [43-45]. Since 2011, the word "China" has appeared frequently, indicating that scholars are paying more attention to China's resources and environment. In the past five years, the terms "circular economy," "energy," and "industrial symbiosis model and evolution" have become hotspots in IE research.

The main keywords of the early stage (1991-2000) of EM research include "sociology," "modernity," "modernization," "sustainable development," and "environmental movement," which mainly focus on the environmental movement, income inequality, women, and social and environmental issues, such as risk society and discussions on modernization, representing the environmental sociological attributes of EM (modernization as a profound change in human society since the industrial revolution, a process of transformation of human society from traditional society to industrial society, and EM is the ecological transformation in the modernization process $[11,46])$. At the beginning of the 21st century, considerations of modernization and modernity continued to be explored, and "policy/politics" began to rise as a high-frequency word. Macro-level solutions were starting to be sought at the level of political and government policy. After 2011, "climate 
change" increased in frequency, "China" has become a hot topic and is receiving continuous attention from the international community. In the past 5 years, new research on urbanization [42] has also emerged.

IE research exhibits a trend of describing the current situation of environmental challenges, exploring methods of analysis and solutions. In comparison, EM focuses more on the national, macro perspective of politics, policy, and government enforcement to explore environmental issues. In terms of research methods, EM mainly applies coordinate analysis methods and policy analysis of modernization research, whereas IE uses more specific analysis and accounting methods, such as LCA, MFA, and IOA.

\subsection{Articles for Interdisciplinary Research}

To analyze the interdisciplinary research articles of IE and EM, a further retrieval was conducted through the WoS database with the search equation "TOPIC = ("industrial ecology" OR "industrial symbiosis")" AND ("ecological modernization" OR "ecological modernisation")," A total of 29 papers with 65 authors were retrieved. After reading the full text, a portion of articles that only dealt with the respective domains of IE or EM were excluded. Finally, 9 articles were screened out as providing valid comments on the relationship between IE and EM, as shown in Table 1.

Table 1. Characteristics of articles involving both IE and EM.

\begin{tabular}{|c|c|c|c|c|c|}
\hline Rank & Reference & Relevant Statement & Country & Year & TC \\
\hline 1 & Ausubel [47] & $\begin{array}{l}\text { "It is plausible to argue that ecological improvements in the North (the } \\
\text { Ecological Modernization of the Developed Nations), increasing energy } \\
\text { efficiency, for example, will in fact weaken the bargaining position of the } \\
\text { South (the Developing Countries), at least in the near term." }\end{array}$ & The United States & 1992 & 13 \\
\hline 2 & Huber [48] & $\begin{array}{l}\text { "The transformation of traditional industrial structures, which are often } \\
\text { environmentally unadapted, to an ecologically modernized, consistent } \\
\text { industrial metabolism implies major or basic technological innovations } \\
\text {.. The notion of industrial ecology is close to the concept of consistency." }\end{array}$ & Germany & 2000 & 120 \\
\hline 3 & Cohen [49] & $\begin{array}{c}\text { "Despite the dilemmas that ecological modernization holds for the } \\
\text { American environmental movement, there are indications that some } \\
\text { groups have begun to embrace industrial ecology, environmentally } \\
\text { conscious manufacturing, and other related modes of } \\
\text { professional practice." }\end{array}$ & The United States & 2006 & 28 \\
\hline 4 & $\begin{array}{l}\text { Geng and Doberstein } \\
\text { [50] }\end{array}$ & $\begin{array}{c}\text { "In essence, the circular economy approach is the same as the more } \\
\text { familiar terms EID and "industrial ecology," and fits comfortably within a } \\
\text { broad range of ecological modernization initiatives pioneered around } \\
\text { the world." }\end{array}$ & Japan & 2008 & 239 \\
\hline 5 & Deutz [8] & $\begin{array}{l}\text { "IE provides important insights to environmental protection derived from } \\
\text { its system's perspective, which are not implied by EM. It thus can suggest } \\
\text { particular routes to approaching EM, and should not be dismissed as } \\
\text { simply a collection of practices that are subsumed within the scope of EM. } \\
\text { IE and EM operate at different, but potentially complementary, scales." }\end{array}$ & The United Kingdom & 2009 & 30 \\
\hline 6 & Anh et al. [51] & $\begin{array}{c}\text { "Designing an integrated model of pollution prevention for industrial } \\
\text { systems usually starts with ... these steps lead us to a } \\
\text { physical-technological model for low-waste industrial systems. The } \\
\text { above mentioned physical-technological models need to be combined } \\
\text { with an analysis of actors and institutions ... Ecological modernization } \\
\text { theory has proved to be a valuable starting point for such } \\
\text { institutional analyses." }\end{array}$ & Vietnam & 2011 & 25 \\
\hline 7 & $\begin{array}{l}\text { Hultman and } \\
\text { Corvellec [52] }\end{array}$ & $\begin{array}{l}\text { "The decoupling of the environmental effects of waste from economic } \\
\text { growth within an ecological modernization paradigm favors increasing } \\
\text { material circulation since this is how environmental success is measured." }\end{array}$ & Sweden & 2012 & 50 \\
\hline 8 & Zhu et al. [53] & $\begin{array}{l}\text { "Rapid economic growth, commensurate with increasing environmental } \\
\text { damage in China, has resulted in officials' further pursuing Eco-industrial } \\
\text { parks (EIP) policy as a significant element of the broader circular } \\
\text { economy and ecological modernization efforts." }\end{array}$ & China & 2014 & 37 \\
\hline 9 & Gregson et al. [54] & $\begin{array}{c}\text { "Circular economies linked to a vision of clean green ecological } \\
\text { modernization are predicated upon enacting the EU as a bounded } \\
\text { material system." }\end{array}$ & The United Kingdom & 2015 & 179 \\
\hline
\end{tabular}

Note: Country: the country where the first institution of the corresponding author is located; PY: publication year; TC: total citation. 
Among them, as early as 1991, in "Industrial ecology: reflections on a colloquium" (presented at the colloquium of the National Academy of Sciences on Industrial Ecology in 1991), Ausubel [47] listed the issue of global north-south differences in EM development as one of the 10 questions discussed in IE at the time. The ecological improvements brought about by the rise of EM in northern countries, such as increased energy efficiency, could lead to a significant reduction in the demand for resources and energy (mainly exported from southern countries to the north), thus widening the gap of economic development of the south and the north. However, from the time this issue was raised to date, there remain relatively few studies in this area. In "Towards eco-agro industrial clusters in aquatic production: the case of the shrimp processing industry in Vietnam," Anh et al. [51] proposed the construction of a physical-technological model for low-waste industrial systems via IE and embedded analysis of the social and institutional environment via EM, demonstrating that the two theories can complement one another in the promotion of industrial change. Additionally, to understand the potential and shortcomings of producer responsibility regulations, Deutz [8] examined the interrelationships of IE and EM in "Producer responsibility in a sustainable development context: ecological modernisation or industrial ecology?." Citing the author's own words, "There is a minimal acknowledgment of EM in the IE literature, and EM literature that is aware of IE tends to dismiss it as simply an eco-efficiency tool for business" [8]. The other six papers include examining IE under the theoretical framework of EM, mainly describing the European environmental management system (e.g., European Waste Hierarchy) and the development of a circular economy in China.

Of the above nine articles, Deutz's [8] study deserves attention, as it is an interdisciplinary study that includes a comparative analysis of IE and EM. By identifying 10 criteria related to the two concepts, such as aim, economic philosophy, origins, etc., careful comparison is made between IE and EM, and the potential that their combination can provide the EU waste minimization policy mechanism is considered. However, the rest of the papers do not provide such a detailed comparative analysis. This demonstrates how few the studies on the intersection of IE and EM are. Notably, there is a lack of clear consensus on the relevant studies and opinions on the relationship between the two.

\section{Comparative Analysis}

\subsection{Origination from the Same Background but with Different Paths}

According to our bibliometric results, IE and EM both emerged around the 1990s, as the expansion of industrial-scale and the heedless use of resources and energy made the contradiction between industrial production, resources, and the environment increasingly prominent. The growing drawbacks of end-of-pipe pollution control and the expanding diversity, complexity, and regionalization (globalization) of environmental problems are common backgrounds for IE and EM. IE is concerned with resource constraints and industrial activities. A more direct approach, such as the 3Rs (reduce, reuse, and recycle), is implemented to improve the efficiency of industrial systems, thus achieving a winwin situation for both economic and environmental benefits. EM, by contrast, explores approaches to solving the contradiction between development and environmental issues at the institutional level, using a top-down perspective, calling for dematerialization, greening, ecologization, and decoupling modernization from environmental degradation [46]. EM envisions a more complex cause-effect relationship, focused on coupling natural and human socioeconomic systems. It does not usually act directly against the producers of pollution and is more influenced by multiple stakeholders on the public side. Essentially, EM pays more attention to social as well as ecological benefits.

IE emerged in large part from the analogy between the industrial ecosystem and the biological ecosystem. The seminal article "Strategies for manufacturing" by Robert Frosch and Nicholas Gallopoulos [55] in Scientific American was the first to discuss the concept of IE and is considered to be the birth of the discipline of IE $[1,43,56]$. By analogizing industrial systems with biological ecosystems, IE explores what the material energy metabolism of 
food chains and the symbiotic relationships among different organisms can tell us about the operation of industrial systems. The metabolic and symbiotic relationships are analogized to industrial metabolism as well as the concept of industrial symbiosis in IE. The concept of industrial metabolism describes the operation and mechanism of industrial activities and explores the causes of environmental pollution through the analysis of the inputs, outputs, and pathways of materials and energy in industrial systems [1,57]. Industrial symbiosis, by contrast, explores methods for improving the efficiency of resource utilization and reducing waste discharge in terms of solid waste exchange and utilization, energy cascade utilization, reclaimed water reuse, and infrastructure sharing [58,59]. Earlier, when the research of the Ministry of International Trade and Industry of Japan, devoted to technology, intended to increase energy efficiency, "Belgium ecosystem" and "industrial metabolism" studies were practical activities using the idea of IE $[56,57]$. The development of the concept of industrial symbiosis in Kalundborg, Denmark, directly contributed to the advancing the theory and application of IE $[60,61]$ and led to the construction of EIPs in more countries afterward (e.g., the United States, The Netherlands, the United Kingdom, China, and Korea). EIPs have also become the main body of IE theory implementation in recent years.

EM originated from the evolution of environmental movements and environmental policies in developed European countries. German sociologists Martin Jänicke and Joseph Huber introduced the environmental policy concept of "ecological modernization" in the 1980 s as an alternative approach to solving environmental challenges [62-64]. Huber (1985) believed that through EM, "the dirty and ugly industrial caterpillar will transform into a[n] ecological butterfly." Gert Spaargaren and Arthur Mol (1992) of Wageningen University and Research in The Netherlands published the first English paper on EM in 1992, elevating it to a theory of social change. The growing environmental movement, at regional and global levels, as well as the increasing interest of international institutions in environmental issues and environmental policy practices, has promoted the development of EM theory [46]. In response to the idea of an ecological collapse and environmental crisis and the debate regarding environment and modernity, EM scholars seek to overcome the ecological crisis through stimulating institutional change and achieving the integration of environmental protection and modern economic development [36]. This is congruent with the concept of sustainable development proposed by the Brundtland Commission [6], which is the integration of ecological quality with economic growth via industrialization.

\subsection{Both Theories Have Their Own Specific Features in Connotations}

Sharing the same target of coordinated development between industrial and environmental systems, both IE and EM are guided by the principles of ecology and indicate a preference for flexible, rather than prescriptive, regulations [8]. Moreover, both emphasize prevention and pursue resource and energy efficiency in strategies developed to address environmental issues. However, because of the disciplinary differences of the research groups, the two theories have focus connotations. The connotation characteristics of both theories are summarized by combing through articles about the connotations of IE and EM.

IE is a discipline that examines the interactions between industrial activities and the environment, involving multiple disciplines, such as bionics, economics, environmental science, ecology, and system dynamics. This endeavor requires a coordinated, rather than isolated, view of the relationship between industrial systems and their surroundings and advocates optimization of the use of material and energy flowing through the socioeconomic system from a life cycle perspective [65]. Many studies define these conceptual connotations [66] as follows: (1) industrial systems mimicking more efficient and sustainable biological ecosystems and promoting cooperative symbiosis between companies [59,67,68]; (2) coordinated development of economic, industrial, and environmental systems, focusing on the enhancement of mutual economic and environmental benefits and the improvement of enterprise competitiveness [67-69]; (3) pollution prevention and efficient use of resources and energy for the whole process, following the principles of the 
3Rs; (4) knowledge exchange and shared use of infrastructure [69]; and (5) transformation of linear open systems to cyclic closed systems [68].

There is no universally accepted definition of the meaning and scope of EM [70]. The concept of EM is discussed by Jänicke [71], Huber [48], Mol [72], Hajer [73], Christoff [74], and He [75]. The connotations of EM can be summarized as involving environmental problem-solving strategies, environmental reform, and industrial transformation, capitalist political and economic restructuring, technology and structural optimization, and the ecological transformation of modernization, including the following: (1) public goods and resource attributes of nature and internalization of external costs [73]; (2) preventive strategies and more advanced environmental technologies [71,72]; (3) technological innovation, institutional innovation, and market mechanisms [76]; (4) intercountry cooperation and multistakeholder involvement, such as that of governments, enterprises, individuals, and environmental non-governmental organizations involved in environmental reform [72,74]; and (5) compatibility between the economy and the environment, pursuing the decoupling of economic growth and environmental degradation [72].

\subsection{From an Isolated to a Syncretic Approach in Research and Practice}

As shown in Table 1, IE and EM currently have experienced a small intersection in research content and methodology because of differences in the context and subject areas in which they arise.

IE is more focused on natural science. By relying on data, IE seeks solutions to resource and environmental conflicts by exploring the operating mechanisms of industrial ecosystems. IE places more emphasis on the whole process of production from the perspective of industrial systems and industrial activities and has clear system boundaries. For example, at the park level, IE scholars study industrial symbiosis and develop EIPs, and at the micro-level, IE researchers require enterprises to develop clean production and green product design. This study summarizes the main research contents of IE: (1) theoretical research and systematic analysis based on methods and models. This includes research on industrial metabolism using MFA, substance flow analysis, IOA, and other approaches, such as material flow and stock analysis conducted in multiple dimensions with metals, nonmetals, urban buildings, and household durable goods [77-81]. The analysis of symbiotic industrial networks using a system of national accounts and ecological network analysis, such as the evaluation of industrial symbiotic network resilience [82], analysis of network structure characteristics, and network evolution; and modeling and evaluation of industrial ecosystem using LCA [83], agent-based modeling [84], and the SD model [85]. (2) Application research based on the planning and design of EIPs. EIPs are the core practice area of IE [7]. For example, construction and development models [86,87]; industrial-urban symbiosis relationship [88]; policy standards [89] and institutional capacity building [90]; performance evaluation, such as industrial symbiosis indicators [91], eco-efficiency [92], and eco-connectance [93]; and practices and case studies, including China, the United States, Europe, Japan, and Korea [43,94-96] are summarized as best practices or transformative paths.

Compared with IE, EM is more oriented to guidance on eco-principles and policy research at the macro-level, covering a wider range of areas, such as climate change at the global/regional level, regional integration/globalization, national environmental policies, institutional reforms, enterprise management, and technological innovation. EM is more closely related to social science, as it mainly uses coordinate and policy analysis methods and emphasizes the participation of multiple stakeholders in environmental reform. There are four main areas of study in EM. One includes the challenges of urbanization, globalization, and the decoupling of the economy and the environment. EM scholars suggest that the degree of impact of economic development on the environment will decrease over time and that the decoupling of economic growth and environmental complications will eventually be achieved through mechanisms such as technological and institutional innovation [76]. A relative decoupling between economic development and emissions has been confirmed 
in developed countries, whereas the relationship between the economy and emissions is stronger in less developed countries [97], the current situation in these countries is on both sides of the inflection point of the Environmental Kuznets Curve (EKC) [98]. The second area of study is environmental policy and management mechanisms. EM researchers advocate the integration of environmental considerations into the policymaking process, denying the central role of government in policymaking [72] and emphasizing the participation of government, enterprises, citizens, and other social forces in environmental policymaking and adopting an open and democratic policy decision-making model [74]. Related studies include analyses of the policy applications of waste management systems in Europe [52], analysis of the case of Sweden [99], and analysis of the institutionalization of environmental policy in the Dutch construction sector [100]. The third area of study is environmental ethics. Environmental ethics involve the exploration of ecological distribution conflicts and environmental justice as a result of the uneven geographical and social distributions of environmental problems [101,102]. Additionally, intensive resource extraction, waste disposal, and land acquisition are often accompanied by heavy, regionally-based environmental and social burdens [103]. Resulting environmental justice movements can reveal new forms of environmental change and preventable injustices while potentially influencing local institutional, technological, or political transformations [102,104-106]. The fourth area of study is enterprise technological innovation and green supply chain management. Technological innovation is one of the core mechanisms of EM. Achieving a shift from "end-of-pipe" treatment technologies to clean technology processes is an aspirational point of concern for EM at the micro-level for companies, yet one of the challenges that companies face is overcoming existing barriers to corporate innovation [107]. Regulation and policy help companies overcome barriers to innovation, allowing the consideration of clean technologies, complementing technological change with organizational change, and exploring opportunities for improvement in strategy and operations [108]. Additionally, green supply chain management has become a new tool of EM [39]. It can help industries to become more sustainable and to achieve collective benefits on the basis of the reuse of waste, by-products, and excess utilities among economically independent industries [109,110]. The complexity of sustainable supply chain design, planning, and management involves technical, economic, environmental, and social issues [111], and EM research and design helps to understand and manage sustainable supply chains [40].

An increasing trend of crossover between IE and EM research and practice is apparent. Although only a small number of articles appeared in the literature keyword search for both IE and EM, research in individual fields seems to regularly address the other. For example, an increasing amount of research on IE focused on policy standards, institutional capacity building, and parks are beginning to consider multifunctionality, networked information sharing, and shared innovation institutions [112,113]. Some scholars have also begun to focus on the issue of multiparticipation in the ecological transformation of industrial parks [114] to avoid the emergence of ecological distribution conflicts [101]. Meanwhile, EM is also exploring concrete, practical approaches, such as the ecological transformation of enterprises and green supply chain management, to address increasingly critical global climate change challenges [39,40].

\section{Discussion}

IE and EM share common goals and economic philosophies, and although they have different origins and disciplinary backgrounds, they are potentially complementary [8]. IE analyzes specific problems related to resource and energy savings from industrial activities based on local to regional, material, product, and process-based system boundaries. EM is dominated by work defined by political boundaries, commonly on a national scale. These scales are complementary in terms of identifying environmental impacts and specific solutions. Whereas environmental policy and ethics problems hindered the crossing of their disciplinary boundaries. 
The applicability and value of EM theory are widely discussed. As an environmental political theory, EM was restricted to developed capitalist countries in the first place. It is worth exploring the value and applicability of EM to developing countries and emerging industrial economies that are facing the contradiction between industrial development and environmental impact in recent years. Subsequent discussions have extended to a global scale, breaking away from the single framework of capitalist societies. Such as IE, EM offers theoretical and practical approaches to sustainable, green development that apply to all countries that are committed to ecological-economic development. Scholars have studied the applicability of EM in countries such as China, Vietnam, and Malaysia [115-118]. EM's concept of technological innovation, market mechanisms, and progressive reforms could provide developing countries useful lessons on environmental reform. However, the limitations cannot be ignored, such as the obstruction of reform by vested interest groups and the inability of policies to solve persistent environmental problems. Hence, it still needs to be refined to fit the specific institutional systems and development status of developing countries.

IE and EM share a common goal of decoupling economic development from environmental burdens. Whether the decoupling that has taken place in some developed countries is genuine involves a question of transfer. International trade and production shifts explain the phenomenon that economic growth in developed countries is accompanied by environmental degradation in less developed countries. For instance, it can be discussed in terms of the shift in the production and consumption of electricity in Turkey [101]. Electricity is vastly consumed in central cities, whereas the rural areas where the power plants are located become "ecological sacrifice zones" [101]. Expanding worldwide, there is a possibility that the place of energy waste generation (pollution) is in less developed countries, whereas the growth of consumption (economic development) occurs in developed countries. Are the less developed countries then reduced to ecological sacrifice zones to support the consumption of more developed countries? This relates to environmental ethics. Multiparty (national) cooperation to develop advanced clean production and pollution prevention technologies while transferring industries to less developed countries is a possible solution to this problem.

The analysis in this paper compares IE and EM in terms of core concerns. Initially, IE was limited to a problem-specific analytical approach and EM to a macro-level analytical model that addresses institutional, social, and other considerations. IE and EM have now expanded into much broader theoretical and practical territories. IE emphasizes optimization, focusing on the redesign of existing industrial systems to achieve higher resource output rates and lower environmental impacts. Although IE research has also addressed the more macro-level environmental policy and social impacts that EM is primarily concerned with, such as global climate change and trade globalization, the academic impact in these areas remains limited. EM emphasizes innovation, which is a breakthrough in existing technological systems and institutional mechanisms and a key driver of system fluctuation. EM is more concerned with upper-level institutional policy design, a broader research breadth that covers all aspects of ecological transformation in the modernization process. EM has delivered less research on the specific measures and quantitative evaluation aspects that IE focuses on and lacks application and practice at the industrial park level. Although the research on the two has uncovered a crossover trend in recent years, most of them still stand on the expansion of research scope from the perspective of their respective disciplines, and few scholars have systematically integrated the two theoretical approaches.

How can the two be synthesized to jointly contribute to a coherent development of economic and environmental performance? A model should be built that incorporates IE system-scale practices (e.g., eco-design, life-cycle analysis, closed-loop manufacturing, and industrial symbiosis) within the policy framework of EM, which includes not only policy-level regulatory management but also system-level analysis and firm-level collaboration. For example, the eco-transformation of industrial parks. An industrial park is not 
just a cluster for industrial enterprises but more an administrative area with integrated socioeconomic attributes. EM can be integrated into the existing industrial park evaluation standard system with IE industrial symbiosis as the core, and not only emphasize the material and energy exchange between enterprises, etc., but also pursue the multifunctionality of the park and fully realize the balanced development of the three dimensions of economy-environment-society for sustainable development [112]. Therefore, it is essential to strengthen the communication between researchers in the natural and social sciences, synthesize the two theories, and build a more comprehensive IE theory system.

\section{Conclusions}

This paper examined the historical literature published on IE and EM from a bibliometric perspective. We searched 4286 published articles on IE and 1024 published articles on EM from the WOS database for bibliometric and comparative analysis. There is a growing trend year by year in IE and EM research, especially in the last decade. IE has a larger number of papers, a broader network of collaboration among authors, and a clearer and specific research content and methodology. The study of EM remains limited to a small number of scholars, as in most developing countries, the priority continues to be that of taking concrete measures to reduce the environmental impact of industrial production processes. Developed countries and regions have conducted more research in both areas because of earlier industrialization. China is an exception as a developing country that has prioritized considerable scientific research and green transformation practices to manage increasingly serious resource and environmental challenges. This paper has also obtained some findings in the comparative analysis of IE and EM. The two theories are both committed to achieving sustainable development and pursuing harmonious economic and ecological development. They share a common historical background, and both follow ecological principles but have different disciplinary origins. Their perspectives in dealing with environmental issues are quite different, thus are their connotation characteristics. IE focuses on specific systemic analysis of enterprises, products, and processes, while EM focuses on macro-level institutional policy analysis. IE and EM are showing a convergent trend in recent years. It is also urgent for developing countries to absorb the two theories in the green transformation process.

There is one notable limitation that we only retrieved data from one database. Given the accessibility, the literature data on IE and EM are only from the WoS database and did not include studies from other databases (e.g., Google Scholar and Scopus). This may have resulted in missing out on some relevant literature but does not change the overall trend. We have also identified some promising directions for future research. First, in the context of globalization, international trade, and industrial transfer are commonplace, the resulting possible resource and environmental inequalities are yet to be revealed. In addition, due to different levels of economic and political development and regional cultures, environmental policies in different countries/regions require to be customized. Finally, the research content needs to be expanded further, for instance, to explore specific ways and feasible evaluation systems for EM implementation at enterprise and industrial park levels. It is hoped that this study can promote the integration of IE and EM in theory and practice to better serve the green transformation of industry and sustainable development of society.

Author Contributions: F.H. conceived the research idea and designed the general framework of the research. Z.F. and N.Y. contributed to literature search, data curation, and writing-original draft preparation; C.W. provided software and graphics guidance. F.H. and D.Y. provided comments and revised the paper. F.S. provided suggestions on comparing the two theories. All authors have read and agreed to the published version of the manuscript.

Funding: This work was supported by the National Natural Science Foundation of China (grant numbers 41801196, 41971255); the Natural Science Foundation of Shandong Province (grant number ZR2019BD021); the Youth Science Funds of Shandong Academy of Sciences (grant number 
2020QN0029); the Taishan Scholar Program of Shandong province and the Think Tank Project of Shandong Academy of Sciences.

Conflicts of Interest: The authors declare no conflict of interest.

\section{References}

1. Shi, L.; Chen, W.Q. Industrial ecology in China: Retrospect and prospect. Acta Ecol. Sin. 2016, 36, 7158-7167. [CrossRef]

2. Azapagic, A. Life cycle assessment and its application to process selection, design and optimisation. Chem. Eng. J. 1999, 73, 1-21. [CrossRef]

3. Bayulken, B.; Huisingh, D. A literature review of historical trends and emerging theoretical approaches for developing sustainable cities (part 1). J. Clean. Prod. 2015, 109, 11-24. [CrossRef]

4. Shi, H.; Tian, J.; Chen, L. China's Quest for Eco-industrial Parks, Part I. J. Ind. Ecol. 2012, 16, 8-10. [CrossRef]

5. Dias, R.; Seixas, P.C.; Lobner, N. Sustainable Development and Ecological Modernization: Boundary Discourses between "Strong" and "Weak" Approaches. J. Sustain. Dev. 2020, 13, 268. [CrossRef]

6. World Commission on Environment and Development. Our Common Future; Oxford University Press: Oxford, UK, 1987.

7. Zeng, D.Z.; Cheng, L.; Shi, L.; Luetkenhorst, W. China's green transformation through eco-industrial parks. World Dev. 2021, 140, 105249. [CrossRef]

8. Deutz, P. Producer responsibility in a sustainable development context: Ecological modernisation or industrial ecology? Geogr. J. 2009, 175, 274-285. [CrossRef]

9. Yang, J.; Wang, R. Retrospect and prospect of industrial ecology. Chin. J. Appl. Ecol. 1998, 9, 555-561.

10. Graedel, T.E. On the concept of industrial ecology. Annu. Rev. Energy Environ. 1996, 21, 69-98. [CrossRef]

11. Li, S.; Zhou, C.; Wang, S. Does modernization affect carbon dioxide emissions? A panel data analysis. Sci. Total Environ. 2019, 663, 426-435. [CrossRef] [PubMed]

12. Liu, Z.; Adams, M.; Wen, Z.; Massard, G.; Dong, H. Review of eco-industrial development around the globe: Recent progress and continuing challenges. Resour. Conserv. Recycl. 2019, 143, 111-113. [CrossRef]

13. Gibbs, D. Ecological modernisation and local economic development: The growth of eco-industrial development initiatives. Int. J. Environ. Sustain. Dev. 2003, 2, 250-266. [CrossRef]

14. Porter, M.E.; Van Der Linde, C. Toward a New Conception of the Environment-Competitiveness Relationship. J. Econ. Perspect. 1995, 9, 97-118. [CrossRef]

15. Yu, C.; Dijkema, G.P.J.; De Jong, M. What Makes Eco-Transformation of Industrial Parks Take Off in China? J. Ind. Ecol. 2015, 19, 441-456. [CrossRef]

16. Van Leeuwen, T.N. The application of bibliometric analyses in the evaluation of social science research. Who benefits from it, and why it is still feasible. Scientometrics 2006, 66, 133-154. [CrossRef]

17. Falagas, M.E.; Pitsouni, E.I.; Malietzis, G.; Pappas, G. Comparison of PubMed, Scopus, Web of Science, and Google Scholar: Strengths and weaknesses. FASEB J. 2007, 22, 338-342. [CrossRef]

18. Zhi, W.; Ji, G. Constructed wetlands, 1991-2011: A review of research development, current trends, and future directions. Sci. Total Environ. 2012, 441, 19-27. [CrossRef]

19. Okubo, Y. Bibliometric Indicators and Analysis of Research Systems: Methods and Examples; OECD Science, Technology and Industry Working Papers, 1997/01; OECD Publishing: Paris, France, 1997; Volume 70.

20. Li, L.-L.; Ding, G.; Feng, N.; Wang, M.-H.; Ho, Y.-S. Global stem cell research trend: Bibliometric analysis as a tool for mapping of trends from 1991 to 2006. Scientometrics 2009, 80, 39-58. [CrossRef]

21. Zhang, Y.; Huang, K.; Yu, Y.; Yang, B. Mapping of water footprint research: A bibliometric analysis during 2006-2015. J. Clean. Prod. 2017, 149, 70-79. [CrossRef]

22. Li, J.; Chen, C. CiteSpace: Text Mining and Visualization in Scientific Literature, 2nd ed.; Capital University of Economics and Business Press: Beijing, China, 2016; ISBN 9787563836834.

23. Van Eck, N.J.; Waltman, L. Software survey: VOSviewer, a computer program for bibliometric mapping. Scientometrics 2009, 84, 523-538. [CrossRef]

24. Ihaka, R.; Gentleman, R. R: A Language for Data Analysis and Graphics. J. Comput. Graph. Stat. 1996, 5, 299. [CrossRef]

25. Bastian, M.; Heymann, S.; Jacomy, M. Gephi: An Open Source Software for Exploring and Manipulating Networks. In Proceedings of the Third International Conference on Weblogs and Social Media, ICWSM, San Jose, CA, USA, 17-20 May 2009 ; pp. 361-362. [CrossRef]

26. Dong, L.; Fujita, T.; Dai, M.; Geng, Y.; Ren, J.; Fujii, M.; Wang, Y.; Ohnishi, S. Towards preventative eco-industrial development: An industrial and urban symbiosis case in one typical industrial city in China. J. Clean. Prod. 2016, 114, 387-400. [CrossRef]

27. Van Berkel, R.; Fujita, T.; Hashimoto, S.; Geng, Y. Industrial and urban symbiosis in Japan: Analysis of the Eco-Town program 1997-2006. J. Environ. Manag. 2009, 90, 1544-1556. [CrossRef] [PubMed]

28. Dong, H.; Ohnishi, S.; Fujita, T.; Geng, Y.; Fujii, M.; Dong, L. Achieving carbon emission reduction through industrial \& urban symbiosis: A case of Kawasaki. Energy 2014, 64, 277-286. [CrossRef]

29. Ivanova, D.; Stadler, K.; Steen-Olsen, K.; Wood, R.; Vita, G.; Tukker, A.; Hertwich, E. Environmental Impact Assessment of Household Consumption. J. Ind. Ecol. 2016, 20, 526-536. [CrossRef] 
30. Stadler, K.; Wood, R.; Bulavskaya, T.; Södersten, C.-J.; Simas, M.; Schmidt, S.; Usubiaga, A.; Acosta-Fernández, J.; Kuenen, J.; Bruckner, M.; et al. EXIOBASE 3: Developing a Time Series of Detailed Environmentally Extended Multi-Regional Input-Output Tables. J. Ind. Ecol. 2018, 22, 502-515. [CrossRef]

31. Wood, R.; Stadler, K.; Simas, M.; Bulavskaya, T.; Giljum, S.; Lutter, S.; Tukker, A. Growth in Environmental Footprints and Environmental Impacts Embodied in Trade: Resource Efficiency Indicators from EXIOBASE3. J. Ind. Ecol. 2018, 22, 553-564. [CrossRef]

32. Pauliuk, S.; Hertwich, E. Socioeconomic metabolism as paradigm for studying the biophysical basis of human societies. Ecol. Econ. 2015, 119, 83-93. [CrossRef]

33. Pauliuk, S.; Majeau-Bettez, G.; Müller, D.B. A General System Structure and Accounting Framework for Socioeconomic Metabolism. J. Ind. Ecol. 2015, 19, 728-741. [CrossRef]

34. York, R.; Rosa, E.A.; Dietz, T. STIRPAT, IPAT and ImPACT: Analytic tools for unpacking the driving forces of environmental impacts. Ecol. Econ. 2003, 46, 351-365. [CrossRef]

35. Adua, L.; Clark, B.; York, R.; Chen, C.-F. Modernizing our way out or digging ourselves in? Reconsidering the impacts of efficiency innovations and affluence on residential energy consumption, 2005-2015. J. Environ. Manag. 2019, 252, 109659. [CrossRef] [PubMed]

36. Spaargaren, G.; Mol, A. Sociology, environment, and modernity: Ecological modernization as a theory of social change. Soc. Nat. Resour. 1992, 5, 323-344. [CrossRef]

37. Mol, A. Environment and Modernity in Transitional China: Frontiers of Ecological Modernization. Dev. Chang. 2006, 37, 29-56. [CrossRef]

38. Mol, A.P.; Spaargaren, G. Environment, Modernity and the Risk-Society: The Apocalyptic Horizon of Environmental Reform. Int. Sociol. 1993, 8, 431-459. [CrossRef]

39. Zhu, Q.; Geng, Y.; Sarkis, J.; Lai, K.-H. Evaluating green supply chain management among Chinese manufacturers from the ecological modernization perspective. Transp. Res. Part E Logist. Transp. Rev. 2011, 47, 808-821. [CrossRef]

40. Zhu, Q.; Sarkis, J.; Lai, K.-H. Green supply chain management innovation diffusion and its relationship to organizational improvement: An ecological modernization perspective. J. Eng. Technol. Manag. 2012, 29, 168-185. [CrossRef]

41. De Jong, M.; Chen, Y.; Joss, S.; Lu, H.; Zhao, M.; Yang, Q.; Zhang, C. Explaining city branding practices in China's three mega-city regions: The role of ecological modernization. J. Clean. Prod. 2018, 179, 527-543. [CrossRef]

42. De Jong, M.; Joss, S.; Schraven, D.; Zhan, C.; Weijnen, M. Sustainable-smart-resilient-low carbon-eco-knowledge cities; making sense of a multitude of concepts promoting sustainable urbanization. J. Clean. Prod. 2015, 109, 25-38. [CrossRef]

43. Heeres, R.R.; Vermeulen, W.J.V.; de Walle, F.B. Eco-industrial park initiatives in the USA and the Netherlands: First lessons. J. Clean. Prod. 2004, 12, 985-995. [CrossRef]

44. Roberts, B. The application of industrial ecology principles and planning guidelines for the development of eco-industrial parks: An Australian case study. J. Clean. Prod. 2004, 12, 997-1010. [CrossRef]

45. Lambert, A.; Boons, F. Eco-industrial parks: Stimulating sustainable development in mixed industrial parks. Technovation 2002, 22, 471-484. [CrossRef]

46. Research Group for China Modernization Strategies. China Modernization Report 2007: A Study on Ecological Modernization; Peking University Press: Beijing, China, 2007; ISBN 9787301113219.

47. Ausubel, J.H. Industrial ecology: Reflections on a colloquium. Proc. Natl. Acad. Sci. USA 1992, 89, 879-884. [CrossRef]

48. Huber, J. Towards industrial ecology: Sustainable development as a concept of ecological modernization. J. Environ. Policy Plan. 2000, 2, 269-285. [CrossRef]

49. Cohen, M.J. Ecological modernization and its discontents: The American environmental movement's resistance to an innovationdriven future. Futures 2006, 38, 528-547. [CrossRef]

50. Geng, Y.; Doberstein, B. Developing the circular economy in China: Challenges and opportunities for achieving 'leapfrog development'. Int. J. Sustain. Dev. World Ecol. 2008, 15, 231-239. [CrossRef]

51. Anh, P.T.; Dieu, T.T.M.; Mol, A.P.; Kroeze, C.; Bush, S.R. Towards eco-agro industrial clusters in aquatic production: The case of shrimp processing industry in Vietnam. J. Clean. Prod. 2011, 19, 2107-2118. [CrossRef]

52. Hultman, J.; Corvellec, H. The European Waste Hierarchy: From the Sociomateriality of Waste to a Politics of Consumption. Environ. Plan. A 2012, 44, 2413-2427. [CrossRef]

53. Zhu, Q.; Geng, Y.; Sarkis, J.; Lai, K.-H. Barriers to Promoting Eco-Industrial Parks Development in China. J. Ind. Ecol. 2014, 19, 457-467. [CrossRef]

54. Gregson, N.; Crang, M.; Fuller, S.; Holmes, H. Interrogating the circular economy: The moral economy of resource recovery in the EU. Econ. Soc. 2015, 44, 218-243. [CrossRef]

55. Frosch, R.A.; Gallopoulos, N.E. Strategies for Manufacturing. Sci. Am. 1989, 261, 144-152. [CrossRef]

56. Erkman, S. Industrial ecology: An historical view. J. Clean. Prod. 1997, 5, 1-10. [CrossRef]

57. Yuan, Z.; Bi, J. Progress and perspectives of industrial ecology: A critical review. Acta Ecol. Sin. 2006, 26, 2709-2715.

58. Chertow, M.R. “Uncovering” Industrial Symbiosis. J. Ind. Ecol. 2007, 11, 11-30. [CrossRef]

59. Chertow, M.R. Industrial Symbiosis: Literature and Taxonomy. Annu. Rev. Energy Environ. 2000, 25, 313-337. [CrossRef]

60. Jacobsen, N.B. Industrial Symbiosis in Kalundborg, Denmark: A Quantitative Assessment of Economic and Environmental Aspects. J. Ind. Ecol. 2006, 10, 239-255. [CrossRef] 
61. Ehrenfeld, J.; Gertler, N. Industrial Ecology in Practice: The Evolution of Interdependence at Kalundborg. J. Ind. Ecol. 1997, 1, 67-79. [CrossRef]

62. Huber, J. Die Verlorene Unschuld der Okologie: Neue Technologien und Superindustrielle Entwicklung [The Lost Innocence of Ecology: New Technologies and Superindustrial Development]; S. Fischer Verlag: Frankfurt, Germany, 1982.

63. Huber, J. Die Regenbogengesellschaft: Okologie and Sozialpolitik [The Rainbow Society: Ecology and Social Policy]; S. Fischer Verlag: Frankfurt, Germany, 1985.

64. Jänicke, M. Preventive Environmental Policy as Ecological Modernisation and Structural Policy; WZB: Berlin, Germany, 1985.

65. Graedel, T.E.; Allenby, B.R. Industrial Ecology, 2nd ed.; Tsinghua University Press: Beijing, China, 2004.

66. Zhang, Y.; Zheng, H.; Chen, B.; Su, M.; Liu, G. A review of industrial symbiosis research: Theory and methodology. Front. Earth Sci. 2014, 9, 91-104. [CrossRef]

67. Chertow, M.R.; Lombardi, D.R. Quantifying Economic and Environmental Benefits of co-located Firms. Environ. Sci. Technol. 2005, 39, 6535-6541. [CrossRef]

68. Harper, E.; Graedel, T.E. Industrial ecology: A teenager's progress. Technol. Soc. 2004, 26, 433-445. [CrossRef]

69. Mirata, M.; Emtairah, T. Industrial symbiosis networks and the contribution to environmental innovation: The case of the Landskrona industrial symbiosis programme. J. Clean. Prod. 2005, 13, 993-1002. [CrossRef]

70. Young, S.C. The Emergence of Ecological Modernisation: Integrating the Environment and the Economy? Routledge: New York, NY, USA, 2000; ISBN 978-1138883352.

71. Jänicke, M. Staatsversagen: Die Ohnmacht der Politik in der Industriegesellschaft; Piper: München, Germany, 1986; ISBN 9783492029841.

72. Mol, A.P.J. Ecological modernization: Industrial transformations and environmental reform. In The International Handbook of Environmental Sociology; Edward Elgar Publishing: Cheltenham, UK, 1997.

73. Hajer, M.A. The Politics of Environmental Discourse: Ecological Modernization and the Policy Process; Oxford University Press: Oxford, UK, 1995.

74. Christoff, P. Ecological modernisation, ecological modernities. Environ. Politics 1996, 5, 476-500. [CrossRef]

75. He, C. Strategic considerations for ecological modernization in China. Bull. Natl. Nat. Sci. Found. China 2007, 6, 333-339. [CrossRef]

76. Jänicke, M. Ecological modernisation: New perspectives. J. Clean. Prod. 2008, 16, 557-565. [CrossRef]

77. Han, F.; Yu, F.; Cui, Z. Industrial metabolism of copper and sulfur in a copper-specific eco-industrial park in China. J. Clean. Prod. 2016, 133, 459-466. [CrossRef]

78. Yang, D.; Gao, L.; Xiao, L.; Wang, R. Cross-boundary environmental effects of urban household metabolism based on an urban spatial conceptual framework: A comparative case of Xiamen. J. Clean. Prod. 2012, 27, 1-10. [CrossRef]

79. Schandl, H.; West, J. Material Flows and Material Productivity in China, Australia, and Japan. J. Ind. Ecol. 2012, 16, 352-364. [CrossRef]

80. Kennedy, C.; Cuddihy, J.; Engel-Yan, J. The Changing Metabolism of Cities. J. Ind. Ecol. 2007, 11, 43-59. [CrossRef]

81. Shi, F.; Huang, T.; Tanikawa, H.; Han, J.; Hashimoto, S.; Moriguchi, Y. Toward a Low Carbon-Dematerialization Society. J. Ind. Ecol. 2012, 16, 493-505. [CrossRef]

82. Valenzuela-Venegas, G.; Henríquez-Henríquez, F.; Boix, M.; Montastruc, L.; Arenas-Araya, F.; Miranda-Pérez, J.; Díaz-Alvarado, F. A resilience indicator for Eco-Industrial Parks. J. Clean. Prod. 2018, 174, 807-820. [CrossRef]

83. Kuo, N.-W.; Chen, P.-H. Quantifying energy use, carbon dioxide emission, and other environmental loads from island tourism based on a life cycle assessment approach. J. Clean. Prod. 2009, 17, 1324-1330. [CrossRef]

84. Ghali, M.R.; Frayret, J.-M.; Ahabchane, C. Agent-based model of self-organized industrial symbiosis. J. Clean. Prod. 2017, 161, 452-465. [CrossRef]

85. Cui, H.; Liu, C.; Côté, R.; Liu, W. Understanding the Evolution of Industrial Symbiosis with a System Dynamics Model: A Case Study of Hai Hua Industrial Symbiosis, China. Sustainability 2018, 10, 3873. [CrossRef]

86. Chertow, M.; Ehrenfeld, J. Organizing Self-Organizing Systems: Toward a Theory of Industrial Symbiosis. J. Ind. Ecol. 2012, 16, 13-27. [CrossRef]

87. Zhang, X.; Chai, L. Structural features and evolutionary mechanisms of industrial symbiosis networks: Comparable analyses of two different cases. J. Clean. Prod. 2019, 213, 528-539. [CrossRef]

88. Kim, H.-W.; Dong, L.; Choi, A.E.; Fujii, M.; Fujita, T.; Park, H.-S. Co-benefit potential of industrial and urban symbiosis using waste heat from industrial park in Ulsan, Korea. Resour. Conserv. Recycl. 2018, 135, 225-234. [CrossRef]

89. Huang, B.; Yong, G.; Zhao, J.; Domenech, T.; Liu, Z.; Chiu, A.S.F.; McDowall, W.; Bleischwitz, R.; Liu, J.; Yao, Y. Review of the development of China's Eco-industrial Park standard system. Resour. Conserv. Recycl. 2019, 140, 137-144. [CrossRef]

90. Wang, Q.; Deutz, P.; Chen, Y. Building institutional capacity for industrial symbiosis development: A case study of an industrial symbiosis coordination network in China. J. Clean. Prod. 2017, 142, 1571-1582. [CrossRef]

91. Felicio, M.; Amaral, D.; Esposto, K.; Durany, X.G. Industrial symbiosis indicators to manage eco-industrial parks as dynamic systems. J. Clean. Prod. 2016, 118, 54-64. [CrossRef]

92. Park, H.-S.; Behera, S.K. Methodological aspects of applying eco-efficiency indicators to industrial symbiosis networks. J. Clean. Prod. 2014, 64, 478-485. [CrossRef] 
93. Tiejun, D. Two quantitative indices for the planning and evaluation of eco-industrial parks. Resour. Conserv. Recycl. 2010, 54, 442-448. [CrossRef]

94. Mirata, M. Experiences from early stages of a national industrial symbiosis programme in the UK: Determinants and coordination challenges. J. Clean. Prod. 2004, 12, 967-983. [CrossRef]

95. Zhu, Q.; Lowe, E.A.; Wei, Y.-A.; Barnes, D. Industrial Symbiosis in China: A Case Study of the Guitang Group. J. Ind. Ecol. 2007, 11, 31-42. [CrossRef]

96. Park, J.M.; Park, J.Y.; Park, H.-S. A review of the National Eco-Industrial Park Development Program in Korea: Progress and achievements in the first phase, 2005-2010. J. Clean. Prod. 2016, 114, 33-44. [CrossRef]

97. Jorgenson, A.; Clark, B. Are the Economy and the Environment Decoupling? A Comparative International Study, 1960-2005. Am. J. Sociol. 2012, 118, 1-44. [CrossRef]

98. Grossman, G.; Krueger, A. Environmental Impacts of a North American Free Trade Agreement; National Bureau of Economic Research: Cambridge, MA, USA, 1991. [CrossRef]

99. Lidskog, R.; Elander, I. Ecological Modernization in Practice? The Case of Sustainable Development in Sweden. J. Environ. Policy Plan. 2012, 14, 411-427. [CrossRef]

100. Melchert, L. The Dutch sustainable building policy: A model for developing countries? Build. Environ. 2007, 42, 893-901. [CrossRef]

101. Aydin, C.I. Identifying Ecological Distribution Conflicts around the Inter-regional Flow of Energy in Turkey: A Mapping Exercise. Front. Energy Res. 2019, 7, 1-19. [CrossRef]

102. Špirić, J. Ecological distribution conflicts and sustainability: Lessons from the post-socialist European semi-periphery. Sustain. Sci. 2018, 13, 661-676. [CrossRef]

103. Martinez-Alier, J.; Kallis, G.; Veuthey, S.; Walter, M.; Temper, L. Social Metabolism, Ecological Distribution Conflicts, and Valuation Languages. Ecol. Econ. 2010, 70, 153-158. [CrossRef]

104. Bullard, R.D. Dumping in Dixie: Race, class, and environmental quality. J. Public Health Policy 1992, 13, 522-523. [CrossRef]

105. Bryant, B.; Mohai, P. Race and the Incidence of Environmental Hazards: A Time for Discourse, 1st ed.; Routledge: London, UK, 1992; ISBN 9780429303661.

106. Avila, S. Environmental justice and the expanding geography of wind power conflicts. Sustain. Sci. 2018, 13, 599-616. [CrossRef]

107. Gouldson, A.; Murphy, J. Ecological Modernisation: Restructuring Industrial Economies. Political Q. 1997, 68, 74-86. [CrossRef]

108. Murphy, J.; Gouldson, A. Environmental policy and industrial innovation: Integrating environment and economy through ecological modernisation. Geoforum 2000, 31, 33-44. [CrossRef]

109. Herczeg, G.; Akkerman, R.; Hauschild, M.Z. Supply chain collaboration in industrial symbiosis networks. J. Clean. Prod. 2018, 171, 1058-1067. [CrossRef]

110. Park, J.; Sarkis, J.; Wu, Z. Creating integrated business and environmental value within the context of China's circular economy and ecological modernization. J. Clean. Prod. 2010, 18, 1494-1501. [CrossRef]

111. Bergendahl, J.A.; Sarkis, J.; Timko, M.T. Transdisciplinarity and the food energy and water nexus: Ecological modernization and supply chain sustainability perspectives. Resour. Conserv. Recycl. 2018, 133, 309-319. [CrossRef]

112. Yang, Y.; Liu, Y. Development status of abroad chemical parks and enlightenment to China. Mod. Chem. Ind. 2020, 40, 1-7. [CrossRef]

113. Liwarska-Bizukojc, E.; Bizukojc, M. Overview of European eco-industrial parks: Evaluation of industrial symbiosis potential. Environ. Eng. Manag. J. 2018, 17, 477-490. [CrossRef]

114. Elmassah, S. Industrial symbiosis within eco-industrial parks: Sustainable development for Borg El-Arab in Egypt. Bus. Strateg. Environ. 2018, 27, 884-892. [CrossRef]

115. Qiao, Y. The successful experience, limitations and inspiration of ecological modernization from the perspective of ecological civilization. Ecol. Econ. 2014, 30, 182-185.

116. Frijns, J.; Phuong, P.T.; Mol, A.P. Developing countries: Ecological modernisation theory and industrialising economies: The case of Viet Nam. Environ. Politics 2000, 9, 257-292. [CrossRef]

117. Hong, D. Economic growth, environmental protection and ecological modernization: A perspective from environmental sociology. Soc. Sci. China 2012, 9, 82-99.

118. Noor Asyhikin Binti Abd Razak; Nor Azlin Binti Tajuddin Ecological modernization: In Malaysia: A review of Pakatan Harapan's manifesto manifesto during the 14th general election within the context of ecological modernization framework. Intellect. Discourse 2020, 28, 241-259. 